\title{
Exchange Rates and Macro News in Emerging MARKETS
}

\author{
Guglielmo Maria Caporale ${ }^{a *}$ Fabio Spagnolo ${ }^{a}$ And Nicola Spagnolo ${ }^{a}, b$ \\ ${ }^{a}$ Department of Economics and Finance, Brunel University London, UK \\ ${ }^{b}$ Centre for Applied Macroeconomic Analysis, Australian National University
}

June 19, 2018

\begin{abstract}
This paper uses a VAR-GARCH(1,1) model to analyse mean and volatility spillovers between macro news (in the form of newspaper headlines) and the exchange rates vis-avis both the US dollar and the euro of the currencies of a group of emerging countries including the Czech Republic, Hungary, Indonesia, Korea, Mexico, Poland, South Africa, Thailand and Turkey over the period 02/1/2003-23/9/2014. The results suggest limited dynamic linkages between the first moments compared to the second moments, causalityin-variance being found in a number of cases; further, the recent global financial crisis appears to have had a significant impact. The conditional correlations also provide evidence of co-movement. Finally, as expected the impact of news is more muted in the case of managed currencies, significant spillovers only being found in the case of foreign news in the crisis period.
\end{abstract}

Keywords: Emerging markets, Exchange Rates, GARCH model, Macro news.

JEL Classification: C32, F36, G15.

${ }^{*}$ We would like to thank the Editor and one anonimous referee for very useful comments and suggestions. We also would like to thank for their useful comments participants to the "Workshop on Financial Globalization" in Cologne/Maastricht, 16-17 February 2017, as well as in seminars at the Dutch National Bank, University of Italian Switzerland (Lugano), University of Padova, GREQAM (Aix-en-Provence), Universidad Autonoma de Madrid and University of Maastricht. Corresponding author: Professor Guglielmo Maria Caporale, Department of Economics and Finance, Brunel University London, UB8 3PH, UK. Tel.: +44 (0)1895 266713. Fax: +44 (0)1895 269770. E-mail: Guglielmo-Maria.Caporale@brunel.ac.uk 


\section{Introduction}

The impact of macro news on exchange rates is a topic that has attracted considerable interest in recent years. According to the efficient market hypothesis (EMH, see Fama, 1970), asset prices should fully reflect all available information and therefore react only to the arrival of new information in the form of "surprises" affecting agents' expectations about future economic activity, and in turn cash flows and the discount factor.

Several papers have investigated the relationship between exchange rate and macroeconomic fundamentals. (Beckmann et al, 2011)

The FX markets are ideally suited to testing this hypothesis and the effects of news since, unlike other financial markets, they are always open and therefore the immediate response of exchange rates to news can be investigated. Daily data have been used in studies such as Galati and Ho (2001), who found asymmetries and time variation in the response of the euro-dollar rate to macro news in 1999-2000. More frequently, high-frequency data have been examined instead; for instance, Almeida et al. (1998) did so for the US dollar- German mark exchange rate, and Andersen et al. (2003) for the US dollar vis-à-vis a number of currencies. Pearce and Solakoglu (2007) extended the analysis vis-à-vis the Japanese yen and the German mark by allowing for threshold effects, asymmetric (depending on the sign of the news) and state-dependent responses (where the phase of the economic cycle is identified on the basis of the deviations from trend of industrial production, as in McQueen and Roley, 1993); they found significant effects of various categories of real news. Related studies include Andersen et al. (2007), Dominguez and Panthaki (2006), Ehrmann and Fratzscher (2005) and Faust et al. (2007).

Intra-day data are also analysed by Cagliesi et al. (2013) for the US dollar/euro exchange rate during the period 2003-2011. Specifically, they consider thrice-daily series for three eight-hour time zones (Asian, European and American) making up the global trading day. An EGARCH $(3,1)$ model is estimated to test for the (possibly asymmetric) effects of fundamentals and both scheduled and unscheduled news. The dynamic analysis shows the dominance of real news, asymmetric reactions to good and bad news, and significant effects of the global financial crisis; in particular, the crisis period is characterised by quicker mean reversion, more asymmetric responses of both conditional mean and volatility to good versus bad news, and a bigger impact of unscheduled and current news. Both asymmetries and state dependence are investigated by Fatum et al. (2009); they find different responses of the US dollar/yen rate depending on the type of news (positive or negative), their country of origin and the phase of the cycle.

The fundamentals thought to affect exchange rates vary depending on the theoretical framework. For instance, in the monetary model relative income and money supply are the key determinants, with real interest rates also playing a role in the presence of price rigidities (see Frankel, 1979). In portfolio balance models the trade balance is instead the main driver: a deficit leads to higher foreign holdings of US assets and a devaluation of the US currency to rebalance the portfolio. The expected behaviour of the central bank can also affect exchange rates; for example, the expectation of higher interest rates generated by positive news about growth would normally result in an appreciation of the currency (unless expected inflation also goes up because of the Phillips curve, in which case a depreciation should occur - see Balduzzi et al,. 2001). 
Heterogeneity of beliefs across market participants might also affect the response of financial variables to news surprises. Pericoli and Veronese (2015) use the dispersion of analysts' forecasts to proxy it and find that its impact on the US dollar/euro exchange rate (as well as the US and German long-term interest rates) in the period from 1999 to 2014 is stronger when forecaster heterogeneity is lower, regardless of the frequency. Further, the response of exchange rates to macro news is time-varying, being muted in periods of unconventional monetary policy. There is also a literature connecting the impact of news in the FX market to order flows (see, e.g., the seminal study by Evans and Lyons, 2008). The key finding is that macro news mainly affect currency prices indirectly through the impact on the volatility of order flows.

Investor psychology could be crucial to explain the relationship between news and financial markets. For instance, in the model by De Long et al. (1990) noise traders react to negative belief shocks by selling shares to rational arbitrageurs (see also Campbell et al., 1993). Coval and Shumway (2001) and Antweiler and Frank (2004) instead relate investor sentiment to trading costs, with the perception of a more negative outlook resulting in lower trading volumes. Belke et al. (2018) assess the impact of the probability of Brexit on the UK and internationalfinancial markets, for both the first and the second statistical moments ; they show that Brexit-induced policy uncertainty will continue to cause instability in key financial markets and has the potential to damage the real economy in both the UK and other European countries. Tetlock (2007) examines the links between media "pessimism" (generated by "bad news") and low investor sentiment in the US by estimating a VAR model. His empirical result suggest that models of noise and liquidity traders can account for the effects of low investor sentiment on financial markets (see also Tetlock et al., 2008). Fang and Peress (2009) use a wider dataset including more US daily newspapers and a cross-section of countries and find that media coverage affects asset prices by disseminating information broadly, even if it does not represent news.

Existing studies on the relationship between macro news and exchange rates mainly concern developed as opposed to emerging FX markets (evidence on emerging equity and bond markets is instead provided by Wongswan, 2006 and Andritzky et al., 2007, respectively). In particular, Cai et al. (2009) consider the effects of US and domestic news announcements on nine emerging markets (Czech Republic, Hungary, Indonesia, Korea, Mexico, Poland, South Africa, Thailand and Turkey). They follow Andersen et al. (2003) and model currency returns as a function of news including lagged effects and heteroscedastic errors, where the latter are the sum of the daily volatility forecast (based on a $\operatorname{GARCH}(1, .1)$ specification), the absolute value of news surprises including lags, and the Fourier flexible for the calendar effect. They find that US news matters more than domestic ones, and increasingly so. The role of market sentiment (proxied by the median value of the FX Consensus Forecasts) and uncertainty (measured by the dispersion of market forecasts) respectively are also investigated, only the former appearing to be statistically significant. Egert and Kocenda (2014) examine the impact of both macro news and central bank communication on FX markets in Central and Eastern European countries (CEECs). Whilst evidence is widely available in the case of the developed countries (see the studies surveyed by Blinder et al., 2008 and Cavusoglu, 2010), this study is a comprehensive one focusing on the CEECs. Having obtained long-run equilibrium exchange rates from a monetary model, they proceed to estimate high-frequency 
GARCH(1,1) models for each currency and find a significant impact of macro news, and also of central bank communications, but only during the crisis period starting in 2008 .

The effects of news surprises could depend on their interpretation by the press read by agents; for this reason, Birz and Lott (2013) use newspaper headlines and find that news on GDP and unemployment affect stock returns in the US. Following them, in the present paper we also consider newspaper coverage of macro news and analyse its effects on exchange rates in our case. ${ }^{1}$

Our study makes a fourhfold contribution. First, it focuses on the relationship between macro news and exchange rates in a group of emerging FX markets (including the Czech Republic, Hungary, Poland, Argentina, Mexico, South Korea, Egypt, Nigeria, and Turkey), for which very limited evidence is available. Exchange rate challenges in emerging markets and developing countries were investigated by Belke et al. (2015). Furthermore, Belke et al. (2017) shed light on the goverment bond transmission mechanism running from US and the eurozone to emerging Asian markets.

Second, in contrast to most existing papers in this area of the literature, it models the dynamic interactions between both the first and the second moments of the variables of interest. Third, it considers exchange rates vis-a-vis both the US dollar and the euro in order to compare these two markets. Finally, it controls for the 2008 financial crisis. The layout is as follows. Section 2 outlines the econometric modelling approach. Section 3 describes the data as well as the exchange rate regimes and policies adopted in the various countries examined, since different currency arrangements might affect the response to news. Section 4 presents the empirical results. Section 5 summarises the main findings and offers some concluding remarks.

\section{The model}

We represent the first and second moments of exchange rate returns (vis-a-vis the US dollar and the euro respectively) and macro news (as reported by newspapers in the form of headlines) in various emerging markets using a VAR-GARCH $(1,1)^{2}$ In its most general specification the model takes the following form:

$$
\mathbf{x}_{t}=\boldsymbol{\alpha}+\boldsymbol{\beta} \mathbf{x}_{t-1}+\boldsymbol{\delta} \mathbf{f}_{t-1}+\mathbf{u}_{t}
$$

where $\mathbf{x}_{t}=\left(\right.$ ExRate Re $t_{t}$,Domestic News Index, USA (Eurozone) News Inde $\left.x_{t}\right)$ and $\mathbf{x}_{t-1}$ is the corresponding vector of lagged variables. We include in the mean equation a vector of control variables given by $\mathbf{f}_{t-1}=\left(\right.$ Interest Rate Differential $t_{t-1}$, Domestic Stock Re $\left.t_{t-1}\right)$, namely the 90-day Treasury Bill rate differential (vis-a-vis the US) and domestic stock returns as proxies for monetary policy and domestic financial shocks. ${ }^{3}$ The residual vector

\footnotetext{
${ }^{1}$ Baker et al. (2015) develop a new index of economic policy uncertainty (EPU) based on newspaper coverage frequency. They find that policy uncertainty innovations foreshadow declines in investment, output, and employment in the US and 12 major economies. Their index is monthly and therefore cannot be used, for comparative purposes, in our analysis

${ }^{2}$ The model is based on the GARCH(1,1)-BEKK representation proposed by Engle and Kroner (1995). This specification was preferred to a set of competing models, such as the DCC-GARCH family models, given the relatively small number of variables and the rather high number of parameters to be estimated.

${ }^{3}$ Unlike Birz and Lott (2011), we do not include news surprises: they find that they are not statistically
} 
$\mathbf{u}_{t}=\left(u_{1, t}, u_{2, t}, u_{3, t}\right)$ is trivariate and normally distributed $\mathbf{u}_{t} \mid I_{t-1} \sim\left(\mathbf{0}, H_{t}\right)$, its conditional variance covariance matrix being given by:

$$
H_{t}=\left[\begin{array}{lll}
h_{11 t} & h_{12 t} & h_{13 t} \\
h_{12 t} & h_{22 t} & h_{23 t} \\
h_{13 t} & h_{23 t} & h_{33 t}
\end{array}\right]
$$

The parameter vector of the mean return equation (1) includes the constant $\boldsymbol{\alpha}=\left(\alpha_{1}, \alpha_{2}, \alpha_{3}\right)$, the autoregressive term, $\boldsymbol{\beta}=\left(\beta_{11}, \beta_{12}+\beta_{12}^{*}, \beta_{13}+\beta_{13}^{*}\left|0, \beta_{22}, 0\right| 0,0, \beta_{33}\right)$, which measures the effect on the mean of exchange rate returns of domestic $\left(\beta_{12}\right)$ and USA/euro $\left(\beta_{13}\right)$ negative macro news as a percentage of total news. Furthermore, $\boldsymbol{\delta}=\left(\delta_{12}, \delta_{13}|0,0| 0,0\right)$ is the vector of control parameters for monetary policy and exogenous shocks respectively, appearing in the first equation only. ${ }^{4}$

The second moment takes the following form ${ }^{5}$ :

$$
H_{t}=C_{0}^{\prime} C_{0}+A_{11}^{\prime}\left[\begin{array}{lll}
e_{1, t-1}^{2} & e_{2, t-1} e_{1, t-1} & e_{3, t-1} e_{1, t-1} \\
e_{1, t-1} e_{2, t-1} & e_{2, t-1}^{2} & e_{3, t-1} e_{2, t-1} \\
e_{1, t-1} e_{3, t-1} & e_{2, t-1} e_{3, t-1} & e_{3, t-1}^{2}
\end{array}\right] A_{11}+G_{11}^{\prime} H_{t-1} G_{11}
$$

where

$$
A_{11}=\left[\begin{array}{lll}
a_{11} & 0 & 0 \\
a_{21}+a_{21}^{*} & a_{22} & 0 \\
a_{31}+a_{31}^{*} & 0 & a_{33}
\end{array}\right] ; G_{11}=\left[\begin{array}{lll}
g_{11} & 0 & 0 \\
g_{21}+g_{21}^{*} & g_{22} & 0 \\
g_{31}+g_{31}^{*} & & g_{33}
\end{array}\right]
$$

Equation (3) models the dynamic process of $H_{t}$ as a linear function of its own past values $H_{t-1}$ and past values of the squared innovations $\left(e_{1, t-1}^{2}, e_{2, t-1}^{2}, e_{3, t-1}^{2}\right)$. The parameters of (3) are given by $C_{0}$ (which is restricted to be upper triangular), and the two matrices $A_{11}$ and $G_{11}$ (with zero restrictions such that only unidirectional volatility spillovers from macro news volatility to exchange rate volatility are allowed). In order to account for the possible effects of the recent financial crisis, we also include a dummy variable (denoted by ${ }^{*}$ ) with a switch on 15 September 2008, i.e. on the day of the collapse of Lehman Brothers. Therefore each of the latter two matrices has four zero restrictions since we are focusing on volatility spillovers (causality-in-variance) from domestic news volatility before $\left(a_{21}\right)$ and after the crisis $\left(a_{21}+a_{21}^{*}\right)$, as well as from USA/Eurozone news volatility before $\left(a_{31}\right)$ and after the crisis $\left(a_{31}+a_{31}^{*}\right)$, to exchange rate returns volatility only, and not viceversa. The BEKK representation guarantees by construction that the covariance matrix in the system is positive

significant, since news are released on a very small percentage of trading days, in contrast to the daily newspaper coverage of macro news, which we model using a GARCH specification. Further, the estimation of a day-of-the-week dummy did not provide evidence of any such effects (these additional results are not reported in the paper).

${ }^{4}$ These variables are treated as exogenous in order to obtain a system of equations of manageable dimensions; both are lagged in order to control for any potential endogeneity and to capture the often noncontemporaneous effects of monetary and financial variables.

${ }^{5}$ The parameters $\left(a_{21}\right)$ and $\left(a_{31}\right)$ in Equation (3) measure the causality effect of domestic and US (eurozone) macro news volatility respectively, the possible effect of the 2008 financial crisis being captured by $\left(a_{21}+a_{21}^{*}\right)$ and $\left(a_{31}+a_{31}^{*}\right)$ instead. 
definite. Furthermore, the conditional correlations between foreign exchange markets and domestic and foreign news respectively are given by:

$$
\boldsymbol{\rho}_{12, t}=h_{12, t} / \sqrt{h_{11, t}} \sqrt{h_{22, t}} \text { and } \boldsymbol{\rho}_{13, t}=h_{13, t} / \sqrt{h_{11, t}} \sqrt{h_{33, t}}
$$

Given a sample of $T$ observations, a vector of unknown parameters $\theta$ and a $3 \times 1$ vector of variables $\mathbf{x}_{t}$, the conditional density function for model (1) is:

$$
f\left(\mathbf{x}_{t} \mid I_{t-1} ; \theta\right)=(2 \pi)^{-1}\left|H_{t}\right|^{-1 / 2} \exp \left(-\frac{\mathbf{u}_{t}^{\prime}\left(H_{t}^{-1}\right) \mathbf{u}_{t}}{2}\right)
$$

The log-likelihood function is:

$$
L=\sum_{t=1}^{T} \log f\left(\mathbf{x}_{t} \mid I_{t-1} ; \theta\right)
$$

where $\theta$ is the vector of unknown parameters. The standard errors are calculated using the quasi-maximum likelihood methods of Bollerslev and Wooldridge (1992), which is robust to the distribution of the underlying residuals.

\section{Empirical Analysis}

\subsection{Data}

We use daily data (from Bloomberg) on the exchange rates vis-a-vis the US dollar and the euro of the currencies of a group of emerging markets (the Czech Republic, Hungary, Poland, Argentina, Mexico, South Korea, Egypt, Nigeria, and Turkey) over the period 02/1/2003 $23 / 9 / 2014$, for a total of 3059 observations, daily returns being defined as the logarithmic differences of exchange rates.

We consider news coverage of four macroeconomic series, i.e. GDP, unemployment, retail sales and durable goods (as in Birz and Lott, 2013). The data for the News Index are collected from Bloomberg where news coverage is proxied by story headlines counts. News headlines were selected using an extensive search string, containing words indicating articles dealing with macro variables, and also allowing to distinguish between articles with a positive or negative connotation towards GDP, unemployment, retail sales and durable goods. News headlines about unemployment and GDP are the most frequent, whereas there is less coverage of retail sales and durable goods releases. The index we use does not distinguish between different types of macro news, since our focus is on the effects of domestic and USA (or Eurozone) macro news, respectively, as reported by the media.

We counted macro news stories with a positive and negative connotation respectively. The daily negative news percentage is defined as negative news/(negative news + positive news) and it is represented by the blue line in Fig. $3 .{ }^{6}$

Please Insert Table 1 and Figures 1-3 about here

\footnotetext{
${ }^{6}$ Note that we do not give assign different weights to news depending on their source. Furthermore, news about an individual country are also included when they appear as part of news on a set of countries.
} 


\subsection{Exchange Rate Regimes Classification}

To interpret the empirical results reported below it is important to be aware of the exchange rate regime chosen by each of the countries in the sample. For this purpose, we follow the classification system developed by the IMF that is based on de facto arrangements, since these might differ from those officially announced by monetary authorities. The criteria used are the degree of flexibility and the existence of formal or informal commitments to an exchange rate path. In this way each of the nine emerging market currencies considered (for the Czech Republic, Hungary, Poland, Argentina, Mexico, South Korea, Egypt, Nigeria, and Turkey) can be classified as belonging to one (or more, in case of regime changes over time) of the following IMF categories:

Exchange Rates within Crawling Bands - The currency is kept within a $\pm 1 \%$ fluctuationband

Managed Floating with No Predetermined Path for the Exchange Rate - The monetary authorities attempt to influence the exchange rate without having a specific exchange rate path or target. The indicators for managing the rate (e.g., balance of payments, international reserves, parallel market developments) leave room for discretion, and adjustments may not be automatic. Intervention may be direct or indirect.

Independently Floating - The exchange rate is market-determined, with any official foreign exchange market intervention aimed at attenuating the rate of change and preventing excessive fluctuations, rather than setting a level for the exchange rate.

Below we provide some information on the currency regimes and the date of their introduction for the countries in our sample:

The Czech Republic - The Czech Republic introduced a flexible exchange rate regime in May 1997. Since November 2013, the koruna has fluctuated within a $2 \%$ band against the euro, with a temporary shift in July 2014. Consequently, the de facto exchange rate arrangement has been retroactively reclassified by the IMF as managed floating, effective from November 2013.

Hungary - The Forint was subject to various crawling pegs until 2008. Since 26 February 2008 it has been floating freely

Poland - In 1991 Poland replaced a fixed exchange rate with a crawling peg. Since 2000, it has followed a policy combining a floating exchange rate with inflation targeting.

Argentina - In January 2002, Argentina soon after adopting a new, provisional fixed exchange rate vis-à-vis the US dollar, abandoned its peg and allowed the peso to float freely.

Mexico - In 1991 the market and controlled exchange rates were unified. Since then the exchange rate has been floating freely.

South Korea- A free float was introduced in 1997. However, following the global financial crisis of 2008 the Korean government imposed restrictive measures to prevent volatile crossborder capital flows.

Egypt - The Egyptian currency had been reclassified several times by the IMF since the Central Bank of Egypt (CBE) announced the adoption of a de jure" Crawling Peg ER Regime" in 2001. In January 2003, the CBE announced a new" Free Floating ER Regime". However, given the evidence casting doubts on this regime actually being followed by the CBE, the IMF revised its classification as follows. In 2004, 2005, and 2006, Egypt's exchange rate regime was classified as a de facto "Managed Floating with no Predetermined Path for ER". For 2008 and 2009, the classification was changed to a de facto "other Conventional Fixed 
Peg Arrangement" with the exchange rate as a nominal anchor. In 2011, the IMF reclassified Egypt's exchange rate regime as a de facto "Craw-Like Arrangement", in 2012 as a de facto "Stabilized Arrangement", and in 2013 again as a de facto "Craw-Like Arrangement" with the exchange rate used as a nominal anchor.

Nigeria - Nigeria maintained fixed exchange rates from the attainment of political independence in 1960 till the breakdown of the Bretton Woods Monetary System in the early 1970s. In January 1999, it abandoned its dual exchange rate regime under which the official rate co-existed with the rates on the Autonomous Foreign Exchange Market (AFEM) and was used for selected government transactions including external debt service. In October 1999, a daily Inter-Bank Foreign Exchange Market (IFEM) replaced the AFEM. Under the IFEM, the Central Bank of Nigeria (CBN) monopoly on the supply of foreign exchange was removed. The CBN, however, remains the principal supplier of foreign exchange in the market and exerts considerable influence on the determination of the exchange rate. In July, 2002, Nigeria reintroduced a bi-weekly Dutch auction system (DAS) as an operational system for its foreign exchange market to replace the interbank foreign exchange market (IFEM). The DAS is a method of exchange rate determination through auction where bidders pay according to their bid rates and the ruling rate corresponds to the last bid rate that clears the market. The move back to a DAS signalled the intention to opt for a freely floating exchange rate that was eventually introduced in June 2016.

Turkey - Free floating was introduced in 2001. However, Implicit Inflation Targeting was followed between 2002 and 2005 and Formal Inflation Targeting has been in place since 2006.

\subsection{Results}

We test for mean and volatility spillovers by placing restrictions on the relevant parameters; in particular, the following null hypotheses are tested: $(i)$ Domestic news affect the exchange rate before the 2008 crisis $\left(\beta_{12}=0\right)$; (ii) Domestic news affect the exchange rate after the 2008 crisis $\left(\beta_{12}^{*}=0\right)$; (iii) USA (Eurozone) news affect the exchange rate before the 2008 crisis $\left(\beta_{13}=0\right)$; (iv) USA (Eurozone) news affect the exchange rate after the 2008 crisis $\left(\beta_{13}^{*}=0\right) ;(v)$ Domestic news volatility affects exchange rate volatility before the 2008 crisis $\left(a_{21}=g_{21}=0\right) ;(v i)$ Domestic news volatility affects exchange rate volatility after the 2008 crisis $\left(a_{21}^{*}=g_{21}^{*}=0\right)$; (vii) USA (Eurozone) news volatility affects exchange rate volatility before the 2008 crisis $\left(a_{31}=g_{31}=0\right.$ ); and finally (viii) USA (Eurozone) news volatility affects exchange rate volatility after the 2008 crisis $\left(a_{31}^{*}=g_{31}^{*}=0\right){ }^{7}$

The descriptive statistics, presented in Table 1 , show that on average the number of positive news releases is bigger than that of negative ones, the latter representing less than $50 \%$ of total news headlines. However, since the onset of the 2008 crisis, negative news releases have become more frequent in all countries. This shift is particularly noticeable in the case of the Czech Republic, Hungary, Poland, Argentina, Egypt, and the USA. News volatility has increased substantially after the crisis for all currencies. In addition, since 2008 there has been a substantial increase in exchange rate volatility vis-a-vis the Euro and the US dollar in all countries (Figures 1 and 2), the single exception occurring in the case of the Egyptian currency vis-a-vis the US dollar. This evidence supports the inclusion of a switch dummy in the model.

\footnotetext{
${ }^{7}$ Joint restrictions (iii) and (iv) are tested by means of a Wald test.
} 
In order to test the adequacy of the models, Ljung-Box portmanteau tests were performed on the standardized and squared standardized residuals. Overall, the results indicate that the VAR-GARCH $(1,1)$ specification is data congruent and captures satisfactorily the persistence of exchange rate changes and their volatility.

The estimated mean of daily exchange rate changes is negative for most currencies (except the Egyptian and Nigerian ones) against the euro (a euro appreciation), and positive in most cases (with the exception of the Mexican, South Korean and Turkish currencies), against the US dollar (a US dollar depreciation). Exchange rate changes are found to exhibit high persistence $\left(g_{11}>0.9\right)$, with the exception of the Argentine exchange rate vis-a-vis the US dollar $\left(g_{11}=0.83\right)$. The estimated VAR-GARCH $(1,1)$ model with the associated robust pvalues and likelihood function values are presented in Tables 2-4. We select the optimal lag length of the mean equation using the Schwarz information criterion. The results suggest that there are limited dynamic linkages between the first moments compared to the second moments.

In particular, as far as the effects of domestic news on exchange rate returns $\left(\beta_{12}\right)$ are concerned, we find positive and significant causality at the standard $5 \%$ significance level in the cases of the Hungarian $\left(\beta_{12}=0.101\right)$ and Polish $\left(\beta_{12}=0.167\right)$ exchange rates vis-a-vis the euro. The financial crisis appears to have strenghtened the spillovers from domestic news only in the case of the exchange rate of the Polish Zloty vis-a-vis the euro $\left(\beta_{12}+\beta_{12}^{*}=0.385\right)$. As for the effects of foreign news, there is evidence of negative and significant causality in the cases of the Argentine and Polish exchange rate vis-a-vis the US dollar, and the Hungarian one vis-a-vis the euro $\left(\beta_{13}=-0.053\right)$. During the crisis period this spillover effect is also found in the cases of the Hungarian and South Korean exchange rates vis-a-vis the US dollar, and the Egyptian one vis-a-vis the euro $\left(\beta_{13}^{*}=-0.111\right)$.

\section{Please Insert Tables 2-4 about here}

Causality effects ${ }^{8}$ in the conditional variance vary in magnitude across countries (note that the signs on cross-market volatilities cannot be determined). It appears that domestic news volatility has an impact on exchange rate volatility in the Czech $\left(a_{21}=0.051\right)$, Polish $\left(a_{21}=0.026\right)$, Argentine $\left(a_{21}=-0.006\right)$, Mexican $\left(a_{21}=0.007\right)$ and South Korean $\left(a_{21}=-0.002\right)$ cases; volatility spillovers are also found from Eurozone news in the cases of Mexico, and from US news in the case of Argentina $\left(a_{31}=0.058\right)$, Mexico $\left(a_{31}=-0.013\right)$ and South Korea $\left(a_{31}=0.005\right)$.

There is also strong evidence that the 2008 crisis affected the causality-in-variance dynamics. In particular, during the crisis domestic news volatility started having an impact in the case of the Egyptian $\left(a_{21}^{*}=-0.008\right)$, Nigerian $\left(a_{21}^{*}=0.006\right)$, Turkish $\left(a_{21}^{*}=0.006\right)$, and Polish exchange rates $\left(a_{21}^{*}=0.002\right)$. Stronger domestic news volatility effects are found in the cases of the Czech $\left(a_{21}+a_{21}^{*}=-0.318\right)$, Argentine $\left(a_{21}+a_{21}^{*}=-0.072\right)$, Polish $\left(a_{21}+a_{21}^{*}=0.192\right)$ and South Korean $\left(a_{21}+a_{21}^{*}=-0.009\right)$ exchange rates. The most sizeable volatility spillovers appear to be from US macro news in the case of the currencies of the Czech Republic $\left(a_{31}^{*}=0.011\right)$, Hungary $\left(a_{31}^{*}=0.008\right)$, Poland $\left(a_{31}^{*}=0.012\right)$, and Egypt $\left(a_{31}^{*}=0.032\right)$ visa-vis the US dollar, and Argentina $\left(a_{31}^{*}=0.011\right)$, South Korea $\left(a_{31}^{*}=0.005\right)$ and Nigeria

\footnotetext{
${ }^{8}$ Please note that the term causality refers to Granger causality and therefore a structural interpretation is not appropriate.
} 
$\left(a_{31}^{*}=0.007\right)$ vis-a-vis the euro. The 2008 crisis has strenghtened volatility spillovers for the currencies of Argentina $\left(a_{31}+a_{31}^{*}=0.090\right)$ and Mexico $\left(a_{31}+a_{31}^{*}=-0.032\right)$ vis-a-vis the US dollar, and for that of Mexico $\left(a_{31}+a_{31}^{*}=0.025\right)$ vis-a-vis the euro.

Also, the exogenous variables considered are statistically significant only for a few countries, the estimated coefficients indicating a negative stock market effect and a positive interest rate differential effect. Trade could be a significant factor driving the exchange rates of emerging markets. However, this hypothesis cannot be tested directly using our framework, given the low frequency nature of the data on trade. Further investigation is needed considering that all nine countries are net exporters of natural resources (Argentina, Mexico, Egypt, Nigeria and Turkey), consumable goods (Czech Republic, Hungary, Poland) or technology (South Korea).

Finally, the conditional correlations obtained from the VAR-GARCH $(1,1)$ model also provide evidence of co-movement between exchange rates and news. Summary (mean and variance) statistics for the conditional correlations, pre- and post- September 2008, are reported in Table 5. In particular, the conditional correlations between domestic news and exchange rate changes are generally negative. The downward shift in pairwise correlations (between exchange rates and the percentage of domestic negative news) is quite evident for all countries after 2008, with the only exception of the South Korean and Nigerian currencies vis-a-vis the Euro, and the Czech and Turkish currencies vis-a-vis the US dollar. As for the correlations between exchange rates and US and Euro macro news, the mean is positive for all eighteen currencies pre-September 2008. In the second subsample the conditional correlations are significantly higher only for four currencies (those of Hungary, Mexico, Egypt and Nigeria) vis-a-vis the US dollar, but for all of them (except the Hungarian one) vis-a-vis the euro. These findings seem to suggest that since the onset of the 2008 crisis domestic news about the state of the individual economies have had a bigger impact on exchange rates than news about the USA and the Eurozone.

\section{Please Insert Table 5 about here}

It is interesting to examine whether any patterns can be detected in the impact of news on exchange rates that might reflect differences in the exchange rate regimes adopted over time as discussed above. As one would expect, in general only free floating currencies respond to news, whilst managed currencies (those of Egypt and Nigeria) do not; in the crisis period foreign news appear to affect all currencies considered regardless of the exchange rate regime in place (volatility spillovers being especially important), whilst domestic news do not have any impact on managed currencies. This is confirmed by the evidence for countries that have moved from some form of peg to free floating or viceversa. Hungary is a case in point. As already mentioned, this country switched in 2008 from crawling bands to free floating; in the former period no spillovers can be found from news to exchange rates, whilst in the latter significant linkages can be detected. The Czech Republic also switched regimes in 2013 (from free floating to a managed exchange rate), but the second sub-sample is too short in this case to identify any differences between regimes in either mean or volatility spillovers. 


\section{Conclusions}

This paper uses a VAR-GARCH(1,1) model to analyse spillovers between macro news and the exchange rates vis-a-vis both the US dollar and the euro of the currencies of a group of emerging countries including the Czech Republic, Hungary, Indonesia, Korea, Mexico, Poland, South Africa, Thailand and Turkey over the period 02/1/2003 - 23/9/2014. It makes several contributions to the existing literature: (i) it considers news in the form of newspaper headlines, that provide an interpretation of macro releases driving agents' investment decisions (Birz and Lott, 2011); (ii) it adopts an econometric framework shedding light on both mean and volatility spillovers; (iii) its coverage of emerging markets is extensive; (iv) it examines the possible effects of the recent global financial crisis; (iv) it controls for domestic monetary policy and other financial shocks. The results suggest limited dynamic linkages between the first moments, a positive (negative) effect of domestic (foreign news) being found only in a few cases. Similarly, mean spillovers in most cases do not appear to have been affected by the 2008 financial crisis. By contrast, there is stronger evidence of causality-invariance, and in many cases the volatility spillover parameters appear to have shifted as a result of the recent financial crisis. The conditional correlations provide further evidence of its impact on the linkages between the second moments, a sizeable downward shift being observed in various cases. Further, the role played by the two proxies included in the model appears to be limited. Finally, as expected the impact of news is more muted in the case of managed currencies, significant spillovers only being found in the case of foreign news in the crisis period. Overall, the key importance of macro news, as a driver of FX markets is confirmed in the case of the emerging economies as well. The potential role of trade will be investigated in future research based on lower frequency data.

\section{References}

[1] Almeida, A., Goodhart, C. and R. Payne (1998), "The effects of macroeconomic news on high frequency exchange rate behaviour", Journal of Financial and Quantitative Analysis, 33, 3, 383-408.

[2] Andersen, T.G., Bollerslev, T., Diebold, F.X. and C. Vega (2003), "Micro effects of macro announcements": real-time price discovery in foreign exchange", American Economic Review, 93, 1, 38-62.

[3] Andersen, T.G., Bollerslev, T., Diebold, F.X. and C. Vega (2007), "Real-time price discovery in global stock, bond and foreign exchange markets", Journal of International Economics, 73, 2, 251-277.

[4] Andritzky, J.R., Groffrey, J.B. and N.T. Tamirisa (2007), "The impact of macroeconomic announcements on emerging market bonds", Emerging Markets Review, 8, 1, 20-37.

[5] Antweiler, W. and M.Z. Frank (2004), "Is all that talk just noise? The information content of Internet stock message boards", Journal of Finance, 59, 1259-1293. 
[6] Balduzzi, P., Elton, E.J. and T.C. Green (2001), "Economic news and the yield curve: evidence from the US Treasury market", Journal of Financial and Quantitative Analysis, $36,4,523-543$.

[7] Baker, S.R., Bloom, N. and Davis, S.J. (2015), "Measuring economic policy uncertainty", NBER Working Paper, No. 21633.

[8] Beckmann, J., Belke, A. and Kuehl, M. (2011), "The stability of the Dollar-Euro exchange rate determination equation - A time-varying coefficient approach", Review of World Economics, 147-1, 11-40.

[9] Belke, A., and Dubova, I. (2018), "International spillovers in global asset markets", Economic Systems, 42-1, 3-17.

[10] Belke, A., and Schnabl, G. (2015),"Exchange rate challenges in emerging markets and developing countries", Review of Development Economics, 19-3, 449-454.

[11] Belke, A., Dubova, I. and Osowski, T. (2018), "Policy uncertainty and international financial markets: The case of Brexit" Applied Economics, 50, 34-35, 3752-3770.

[12] Belke, A., Dubova, I. and, Volz, U. (2017), "Bond yield spillovers from major advanced economies to emerging Asia", Pacific Economic Review, 23-1, 109-126

[13] Birz, G. and J.R. Lott (2013), "The effect of macroeconomic news on stock returns: new evidence from newspaper coverage", Journal of Banking and Finance, 35, 2791-2800.

[14] Blinder, A.S., Ehrmann, M., Fratzscher, M., Haan, J.D. and D.-J. Jansen (2008), "Central bank communication and monetary policy: a survey of theory and evidence", Journal of Economic Literature, 46, 4, 910-945).

[15] Cagliesi, G., Della Bina, A.C.F. and M. Tivegna (2013), "Euro-Dollar exchange rate and news: Market behaviour before and after the 2007-2008 financial crisis", University of Greenwich, mimeo.

[16] Cai, F., Joo, H. and Z. Zhang (2009), "The impact of macroeconomic announcements on real time foreign exchange rates in emerging markets", Board of Governors of the Federal Reserve System, International Finance Discussion Paper no. 973.

[17] Calvo, G. A., and C. M. Reinhart (2002). "Fear of floating", Quarterly Journal of Economics, 117, 2, 379-408.

[18] Campbell, J.Y., Grossman, S.J. and J. Wang (1993), "Trading volume and serial correlation in stock returns", Quarterly Journal of Economics, 108, 905-939.

[19] Cavosuglu, N. (2010), "Exchange rates and the effectiveness of actual and oral interventions: A survey on findings, issues and policy implications", Global Economic Journal, $10,4,1-40$.

[20] Coval, J.D. and T. Shumway (2001), "Is sound just noise?", Journal of Finance, 56, 1887-1910. 
[21] De Long., Shleifer, A., Summers, L.H. and R.J. Waldmann (1990), "Noise trader risk in financial markets", Journal of Political Economy, 98-703-738.

[22] Dominguez, K.M.E. and F. Panthaki (2006), "What defines 'News' in foreign exchange markets?", Journal of International Money and Finance, 25, 1, 168-198.

[23] Egert, B. and E. Kocenda (2014), "The impact of macro news and central bank communication on emerging European forex markets", Economic Systems, 38, 1, 73-88.

[24] Ehrmann, M. and M. Fratzscher (2005), "Exchange rates and fundamentals: new evidence from real-time data", Journal of International Money and Finance, 24, 2, 317-341.

[25] Engle, R.F., and K.F. Kroner (1995), "Multivariate simultaneous generalized ARCH", Econometric Theory, 11, 122-150.

[26] Evans, M.D.D. and R.K. Lyons (2008), "How is macro news transmitted to exchange rates?", Journal of Financial Economics, 88, 1, 26-50.

[27] Fama, E.F. (1970), "Efficient capital markets: A review of theory and empirical work", Journal of Finance, 25, 2, 383-417.

[28] Fang, L. and J. Peress (2009), "Media coverage and the cross-section of stock returns", Journal of Finance, 64, 5, 2023-2052.

[29] Faust, J., Rogers, J.H., Wang, S.-Y.B. and J.H. Wright (2007), "The high-frequency response of exchange rates and interest rates to macroeconomic announcements", Journal of Monetary Economics, 54, 4, 1051-1068.

[30] Frankel, J.A. (1979), "On the mark: a theory of floating exchange rates based on real interest differentials", American Economic Review, 69, 4, 610-622.

[31] Galati, G. and C. Ho (2001), "Macroeconomic news and the euro/dollar exchange rate", BIS WP no. 105, Bank for International Settlements, Basel, Switzerland.

[32] Ljung, G.M. and G.E.P. Box (1978), "On a measure of lack of fit in time series models", Biometrika 65, 297-303.

[33] McQueen, G. and V.V. Roley (1993), "Stock prices, news, and business conditions", Review of Financial Studies, 6, 3, 683-707.

[34] Pearce, D.K. and M. N. Solakoglu (2007), "Macroeconomic news and exchange rates", Journal of Financial Markets, Institutions and Money, 17, 4, 307-325.

[35] Pericoli, M. and G. Veronese (2015), "Forecaster heterogeneity, surprises and financial markets", WP no. 1020, Bank of Italy, Rome.

[36] Tetlock, P.C. (2007), "Giving content to investor sentiment: the role of media in the stock market", Journal of Finance, 62, 3, 1139-1168.

[37] Tetlock, P.C., Saar-Tsechansky, M. and S. Macskassy (2008), "More than words: quantifying language to measure firms 'fundamentals", Journal of Finance, 63, 1437-1467. 
[38] Wongswan, J. (2006), "Transmission of information across international equity markets". Review of Financial Studies, 19, 4, 1157-1189. 
Table 1: Descriprive Statistics

\begin{tabular}{|c|c|c|c|c|c|c|c|c|}
\hline & \multicolumn{4}{|c|}{ Pre 2008} & \multicolumn{4}{|c|}{ Post 2008} \\
\hline \multicolumn{9}{|c|}{ News Index (\%Negative News over Total News) } \\
\hline & & Mean & S.D. & & & Mean & S.D. & \\
\hline Czech Rep. & & 0.49 & 0.07 & & & 0.51 & 0.12 & \\
\hline Hungary & & 0.49 & 0.11 & & & 0.51 & 0.16 & \\
\hline Poland & & 0.49 & 0.12 & & & 0.51 & 0.18 & \\
\hline Argentina & & 0.48 & 0.12 & & & 0.51 & 0.19 & \\
\hline Mexico & & 0.47 & 0.14 & & & 0.49 & 0.18 & \\
\hline South Korea & & 0.48 & 0.12 & & & 0.48 & 0.21 & \\
\hline Egypt & & 0.49 & 0.05 & & & 0.51 & 0.15 & \\
\hline Nigeria & & 0.49 & 0.07 & & & 0.49 & 0.13 & \\
\hline Turkey & & 0.48 & 0.12 & & & 0.49 & 0.17 & \\
\hline Eurozone & & 0.43 & 0.18 & & & 0.49 & 0.21 & \\
\hline USA & & 0.48 & 0.17 & & & 0.51 & 0.18 & \\
\hline \multicolumn{9}{|c|}{ Exchange Rate Returns } \\
\hline & \multicolumn{2}{|c|}{ US Dollar } & \multicolumn{2}{|c|}{ Euro } & \multicolumn{2}{|c|}{ US Dollar } & \multicolumn{2}{|c|}{ Euro } \\
\hline & Mean & S.D. & Mean & S.D. & Mean & S.D. & Mean & S.D. \\
\hline Czech Rep. & 0.11 & 0.56 & -0.07 & 0.32 & 0.02 & 0.92 & 0.01 & 0.49 \\
\hline Hungary & 0.02 & 0.81 & 0.03 & 0.55 & 0.03 & 1.17 & 0.02 & 0.76 \\
\hline Poland & 0.03 & 0.71 & 0.01 & 0.56 & 0.03 & 1.14 & 0.02 & 0.73 \\
\hline Argentina & 0.01 & 0.46 & 0.02 & 0.72 & 0.06 & 0.42 & 0.05 & 0.76 \\
\hline Mexico & 0.01 & 0.47 & 0.02 & 0.69 & 0.02 & 0.89 & 0.01 & 0.85 \\
\hline South Korea & 0.01 & 0.47 & 0.02 & 0.71 & 0.01 & 0.96 & 0.02 & 1.07 \\
\hline Egypt & 0.01 & 0.22 & 0.01 & 0.65 & 0.02 & 0.16 & 0.01 & 0.68 \\
\hline Nigeria & 0.01 & 0.53 & 0.02 & 0.88 & 0.02 & 0.54 & 0.01 & 0.88 \\
\hline Turkey & 0.02 & 0.86 & 0.01 & 0.90 & 0.04 & 0.87 & 0.03 & 0.96 \\
\hline
\end{tabular}

Note: Exchange rater changes are the percentage changes in exchange rates. News Index refers to the daily negative news media coverage percentage, defined as negative news/(negative news + positive news). Please note that descriptive statistics refer to raw daily data (story counts). The sample size covers the period 02/1/2003-23/9/2014, for a total of 3059 observations. 
Table 2: Exchange rate vis-a-vis the US dollar and the euro

\begin{tabular}{|c|c|c|c|c|c|c|}
\hline & \multicolumn{2}{|c|}{ Czech Republic } & \multicolumn{2}{|c|}{ Hungary } & \multicolumn{2}{|c|}{ Poland } \\
\hline & US Dollar & Euro & US Dollar & Euro & US Dollar & Euro \\
\hline & \multicolumn{6}{|c|}{ Conditional Mean Equation } \\
\hline$\alpha_{1}$ & $\begin{array}{l}0.071 \\
(0.000)\end{array}$ & $\begin{array}{c}-0.027 \\
(0.000)\end{array}$ & $\begin{array}{l}0.004 \\
(0.958)\end{array}$ & $\begin{array}{c}-0.036 \\
(0.025)\end{array}$ & $\begin{array}{l}0.034 \\
(0.567)\end{array}$ & $\begin{array}{c}-0.055 \\
(0.028)\end{array}$ \\
\hline$\alpha_{2}$ & $\begin{array}{l}0.459 \\
(0.000)\end{array}$ & $\begin{array}{l}0.462 \\
(0.000)\end{array}$ & $\begin{array}{l}0.471 \\
(0.000)\end{array}$ & $\begin{array}{l}0.471 \\
(0.000)\end{array}$ & $\begin{array}{l}0.476 \\
(0.000)\end{array}$ & $\begin{array}{l}0.476 \\
(0.000)\end{array}$ \\
\hline$\alpha_{3}$ & $\begin{array}{l}0.425 \\
(0.000)\end{array}$ & $\begin{array}{l}0.448 \\
(0.000)\end{array}$ & $\begin{array}{l}0.449 \\
(0.000)\end{array}$ & $\begin{array}{l}0.451 \\
(0.000)\end{array}$ & $\begin{array}{l}0.452 \\
(0.000)\end{array}$ & $\begin{array}{l}0.449 \\
(0.000)\end{array}$ \\
\hline$\beta_{11}$ & & & & & & $\begin{array}{l}0.063 \\
(0.029)\end{array}$ \\
\hline$\beta_{12}$ & & & & $\begin{array}{l}0.101 \\
(0.050)\end{array}$ & & $\begin{array}{l}0.167 \\
(0.000)\end{array}$ \\
\hline$\beta_{12}^{*}$ & & & & & & $\begin{array}{c}-0.118 \\
(0.035)\end{array}$ \\
\hline$\beta_{13}$ & & & & $\begin{array}{c}-0.053 \\
(0.046)\end{array}$ & $\begin{array}{l}-0.165 \\
(0.036)\end{array}$ & \\
\hline$\beta_{13}^{*}$ & & & $\begin{array}{c}-0.302 \\
(0.031)\end{array}$ & & & \\
\hline$\delta_{12}$ & $\begin{array}{c}-0.051 \\
(0.000)\end{array}$ & $\begin{array}{c}-0.044 \\
(0.000)\end{array}$ & & & & \\
\hline \multirow[t]{2}{*}{$\delta_{13}$} & & $\begin{array}{l}0.066 \\
(0.000)\end{array}$ & & & & \\
\hline & \multicolumn{6}{|c|}{ Conditional Variance Equation } \\
\hline$g_{11}$ & $\begin{array}{l}0.912 \\
(0.000)\end{array}$ & $\begin{array}{l}0.911 \\
(0.000)\end{array}$ & $\begin{array}{c}-0.907 \\
(0.000)\end{array}$ & $\begin{array}{c}-0.946 \\
(0.000)\end{array}$ & $\begin{array}{l}-0.972 \\
(0.000)\end{array}$ & $\begin{array}{c}-0.967 \\
(0.000)\end{array}$ \\
\hline$g_{21}$ & & & & & & \\
\hline$g_{21}^{*}$ & & & $\begin{array}{c}-0.061 \\
(0.041)\end{array}$ & & & \\
\hline$g_{22}$ & $\begin{array}{l}0.993 \\
(0.000)\end{array}$ & $\begin{array}{l}0.992 \\
(0.000)\end{array}$ & $\begin{array}{c}-0.769 \\
(0.000)\end{array}$ & $\begin{array}{l}0.996 \\
(0.000)\end{array}$ & $\begin{array}{l}0.996 \\
(0.000)\end{array}$ & $\begin{array}{l}0.467 \\
(0.000)\end{array}$ \\
\hline$g_{31}$ & $\begin{array}{c}-0.002 \\
(0.048)\end{array}$ & & & & & \\
\hline$g_{31}^{*}$ & $\begin{array}{c}-0.003 \\
(0.007)\end{array}$ & & & & & \\
\hline$g_{33}$ & $\begin{array}{l}0.992 \\
(0.000)\end{array}$ & $\begin{array}{c}-0.992 \\
(0.000)\end{array}$ & $\begin{array}{l}0.986 \\
(0.000)\end{array}$ & $\begin{array}{c}0.991 \\
(0.000)\end{array}$ & $\begin{array}{l}0.989 \\
(0.000)\end{array}$ & $\begin{array}{l}0.988 \\
(0.000)\end{array}$ \\
\hline$a_{11}$ & $\begin{array}{c}-0.492 \\
(0.000)\end{array}$ & $\begin{array}{c}-0.508 \\
(0.000)\end{array}$ & $\begin{array}{c}-0.350 \\
(0.000)\end{array}$ & $\begin{array}{l}0.309 \\
(0.000)\end{array}$ & $\begin{array}{l}0.223 \\
(0.000)\end{array}$ & $\begin{array}{c}-0.069 \\
(0.050)\end{array}$ \\
\hline$a_{21}$ & $\begin{array}{l}0.051 \\
(0.038)\end{array}$ & & & & & $\begin{array}{l}0.026 \\
(0.046)\end{array}$ \\
\hline$a_{21}^{*}$ & $\begin{array}{c}-0.369 \\
(0.000)\end{array}$ & & & & $\begin{array}{l}0.002 \\
(0.037)\end{array}$ & $\begin{array}{l}0.166 \\
(0.000)\end{array}$ \\
\hline$a_{22}$ & $\begin{array}{l}0.102 \\
(0.000)\end{array}$ & $\begin{array}{l}0.099 \\
(0.000)\end{array}$ & $\begin{array}{l}0.180 \\
(0.035)\end{array}$ & $\begin{array}{l}0.065 \\
(0.000)\end{array}$ & $\begin{array}{l}0.074 \\
(0.035)\end{array}$ & $\begin{array}{l}0.057 \\
(0.000)\end{array}$ \\
\hline$a_{31}$ & & & & & & \\
\hline$a_{31}^{*}$ & $\begin{array}{l}0.011 \\
(0.021)\end{array}$ & & $\begin{array}{l}0.008 \\
(0.014)\end{array}$ & & $\begin{array}{c}0.012 \\
(0.028)\end{array}$ & \\
\hline$a_{33}$ & $\begin{array}{l}0.121 \\
(0.050)\end{array}$ & $\begin{array}{l}0.120 \\
(0.000)\end{array}$ & $\begin{array}{l}0.155 \\
(0.000)\end{array}$ & $\begin{array}{l}0.128 \\
(0.000)\end{array}$ & $\begin{array}{l}0.143 \\
(0.000)\end{array}$ & $\begin{array}{l}0.139 \\
(0.000)\end{array}$ \\
\hline LogLik & 2534.76 & 3051.68 & 1528.55 & 1102.38 & 1336.66 & 1346.75 \\
\hline$L B$ & 11.05 & 7.34 & 6.59 & 8.97 & 5.32 & 9.11 \\
\hline$L B^{2}$ & 9.01 & 7.22 & 10.35 & 3.17 & 4.66 & 7.61 \\
\hline
\end{tabular}


Note: P-values are calculated using the quasi-maximum likelihood method of Bollerslev and Wooldridge (1992), which is robust to the distribution of the underlying residuals. Parameters not statistically significant at the $5 \%$ level are not reported. $\mathrm{LB}$ and $\mathrm{LB}^{2}$ are the Ljung-Box test (1978) of significance of autocorrelations of ten lags in the standardized and standardized squared residuals respectively. The parameters $\beta_{12}$ and $\beta_{13}$ measure the Granger causality effect of domestic and USA (Euro area) macro news on exchange rates respectively,.$a_{21}$ and $a_{31}$ measure the causality in variance effect. The effect of the 2008 financial crises on exchange rates is measured by $\left(\beta_{12}+\beta_{12}^{*}\right)$ and $\left(\beta_{13}+\beta_{13}^{*}\right)$ whereas $\left(a_{21}+a_{21}^{*}\right)$ and $\left(a_{31}+a_{31}^{*}\right)$ capture the effect on exchange rate return volatilities. The covariance stationarity condition is satisfied by all the estimated models, all the eigenvalues of $A_{11} \otimes A_{11}+G_{11} \otimes G_{11}$ being less than one in modulus. 
Table 3: Exchange rate vis-a-vis the US dollar and the euro

\begin{tabular}{|c|c|c|c|c|c|c|}
\hline & \multicolumn{2}{|c|}{ Argentina } & \multicolumn{2}{|c|}{ Mexico } & \multicolumn{2}{|c|}{ South Korea } \\
\hline & US Dollar & Euro & US Dollar & Euro & US Dollar & Euro \\
\hline & \multicolumn{6}{|c|}{ Conditional Mean Equation } \\
\hline$\alpha_{1}$ & $\begin{array}{l}0.075 \\
(0.000)\end{array}$ & $\begin{array}{c}-0.044 \\
(0.173)\end{array}$ & $\begin{array}{c}-0.001 \\
(0.998)\end{array}$ & $\begin{array}{c}-0.001 \\
(0.098)\end{array}$ & $\begin{array}{c}-0.001 \\
(0.967)\end{array}$ & $\begin{array}{c}-0.012 \\
(0.759)\end{array}$ \\
\hline$\alpha_{2}$ & $\begin{array}{l}0.489 \\
(0.000)\end{array}$ & $\begin{array}{l}0.487 \\
(0.000)\end{array}$ & $\begin{array}{l}0.486 \\
(0.000)\end{array}$ & $\begin{array}{l}0.481 \\
(0.000)\end{array}$ & $\begin{array}{l}0.468 \\
(0.000)\end{array}$ & $\begin{array}{l}0.470 \\
(0.000)\end{array}$ \\
\hline$\alpha_{3}$ & $\begin{array}{l}0.446 \\
(0.000)\end{array}$ & $\begin{array}{l}0.452 \\
(0.000)\end{array}$ & $\begin{array}{l}0.444 \\
(0.000)\end{array}$ & $\begin{array}{l}0.442 \\
(0.000)\end{array}$ & $\begin{array}{l}0.444 \\
(0.000)\end{array}$ & $\begin{array}{l}0.452 \\
(0.000)\end{array}$ \\
\hline$\beta_{11}$ & $\begin{array}{c}-0.122 \\
(0.083)\end{array}$ & & $\begin{array}{c}-0.077 \\
(0.001)\end{array}$ & & & $\begin{array}{c}-0.189 \\
(0.000)\end{array}$ \\
\hline \multicolumn{7}{|l|}{$\beta_{12}$} \\
\hline$\beta_{13}$ & $\begin{array}{c}-0.052 \\
(0.050)\end{array}$ & & & & & \\
\hline$\beta_{13}^{*}$ & & & & & $\begin{array}{c}-0.116 \\
(0.049)\end{array}$ & \\
\hline$\delta_{12}$ & $\begin{array}{c}-0.008 \\
(0.003)\end{array}$ & & & & & \\
\hline \multicolumn{7}{|l|}{$\delta_{13}$} \\
\hline & \multicolumn{6}{|c|}{ Conditional Variance Equation } \\
\hline$g_{11}$ & $\begin{array}{l}0.830 \\
(0.000)\end{array}$ & $\begin{array}{l}-0.938 \\
(0.000)\end{array}$ & $\begin{array}{c}-0.953 \\
(0.000)\end{array}$ & $\begin{array}{l}0.959 \\
(0.000)\end{array}$ & $\begin{array}{l}-0.949 \\
(0.000)\end{array}$ & $\begin{array}{c}-0.962 \\
(0.000)\end{array}$ \\
\hline$g_{21}$ & $\begin{array}{l}0.012 \\
(0.000)\end{array}$ & $\begin{array}{l}0.003 \\
(0.000)\end{array}$ & & $\begin{array}{c}-0.001 \\
(0.024)\end{array}$ & & $\begin{array}{l}0.009 \\
(0.091)\end{array}$ \\
\hline$g_{21}^{*}$ & $\begin{array}{l}0.157 \\
(0.057)\end{array}$ & & & & & $\begin{array}{c}-0.130 \\
(0.058)\end{array}$ \\
\hline$g_{22}$ & $\begin{array}{l}0.999 \\
(0.000)\end{array}$ & $\begin{array}{c}-0.999 \\
(0.000)\end{array}$ & $\begin{array}{c}-0.990 \\
(0.000)\end{array}$ & $\begin{array}{l}0.988 \\
(0.000)\end{array}$ & $\begin{array}{l}0.996 \\
(0.000)\end{array}$ & $\begin{array}{l}0.996 \\
(0.000)\end{array}$ \\
\hline$g_{31}$ & $\begin{array}{l}0.023 \\
(0.000)\end{array}$ & & $\begin{array}{l}-0.017 \\
(0.057)\end{array}$ & $\begin{array}{c}-0.002 \\
(0.054)\end{array}$ & & \\
\hline$g_{31}^{*}$ & & & $\begin{array}{c}-0.026 \\
(0.007)\end{array}$ & & & \\
\hline$g_{33}$ & $\begin{array}{c}-0.987 \\
(0.000)\end{array}$ & $\begin{array}{c}-0.991 \\
(0.000)\end{array}$ & $\begin{array}{l}0.988 \\
(0.000)\end{array}$ & $\begin{array}{l}0.990 \\
(0.000)\end{array}$ & $\begin{array}{l}0.991 \\
(0.000)\end{array}$ & $\begin{array}{l}0.991 \\
(0.000)\end{array}$ \\
\hline$a_{11}$ & $\begin{array}{c}-0.751 \\
(0.000)\end{array}$ & $\begin{array}{l}0.339 \\
(0.000)\end{array}$ & $\begin{array}{l}0.284 \\
(0.000)\end{array}$ & $\begin{array}{l}0.299 \\
(0.012)\end{array}$ & $\begin{array}{l}0.294 \\
(0.000)\end{array}$ & $\begin{array}{l}0.262 \\
(0.000)\end{array}$ \\
\hline$a_{21}$ & $\begin{array}{c}-0.006 \\
(0.003)\end{array}$ & & & $\begin{array}{l}0.007 \\
(0.043)\end{array}$ & & $\begin{array}{c}-0.002 \\
(0.043)\end{array}$ \\
\hline$a_{21}^{*}$ & $\begin{array}{l}-0.066 \\
(0.000)\end{array}$ & $\begin{array}{l}0.012 \\
(0.000)\end{array}$ & & & & $\begin{array}{c}-0.007 \\
(0.000)\end{array}$ \\
\hline$a_{22}$ & $\begin{array}{c}-0.024 \\
(0.003)\end{array}$ & $\begin{array}{c}-0.012 \\
(0.000)\end{array}$ & $\begin{array}{l}0.128 \\
(0.000)\end{array}$ & $\begin{array}{c}-0.144 \\
(0.000)\end{array}$ & $\begin{array}{l}0.089 \\
(0.000)\end{array}$ & $\begin{array}{l}0.081 \\
(0.000)\end{array}$ \\
\hline$a_{31}$ & $\begin{array}{l}0.058 \\
(0.000)\end{array}$ & & $\begin{array}{c}-0.013 \\
(0.008)\end{array}$ & $\begin{array}{l}0.010 \\
(0.001)\end{array}$ & & \\
\hline$a_{31}^{*}$ & $\begin{array}{l}0.032 \\
(0.070)\end{array}$ & $\begin{array}{l}0.011 \\
(0.074)\end{array}$ & $\begin{array}{c}-0.019 \\
(0.001)\end{array}$ & $\begin{array}{l}0.015 \\
(0.009)\end{array}$ & $\begin{array}{l}0.005 \\
(0.085)\end{array}$ & $\begin{array}{l}0.005 \\
(0.092)\end{array}$ \\
\hline$a_{33}$ & $\begin{array}{l}0.148 \\
(0.000)\end{array}$ & $\begin{array}{c}-0.125 \\
(0.000)\end{array}$ & $\begin{array}{l}0.147 \\
(0.000)\end{array}$ & $\begin{array}{l}0.129 \\
(0.000)\end{array}$ & $\begin{array}{l}0.129 \\
(0.000)\end{array}$ & $\begin{array}{l}0.130 \\
(0.000)\end{array}$ \\
\hline LogLik & 2890.14 & 2228.44 & 1796.24 & 2157.37 & 2930.42 & 2968.61 \\
\hline$L B$ & 4.57 & 3.16 & 9.11 & 2.69 & 5.29 & 4.09 \\
\hline$L B^{2}$ & 8.55 & 8.75 & 7.93 & 5.42 & 7.02 & 5.91 \\
\hline
\end{tabular}

Note: Please see Table 3. 
Table 4: Exchange rate vis-a-vis the US dollar and the euro

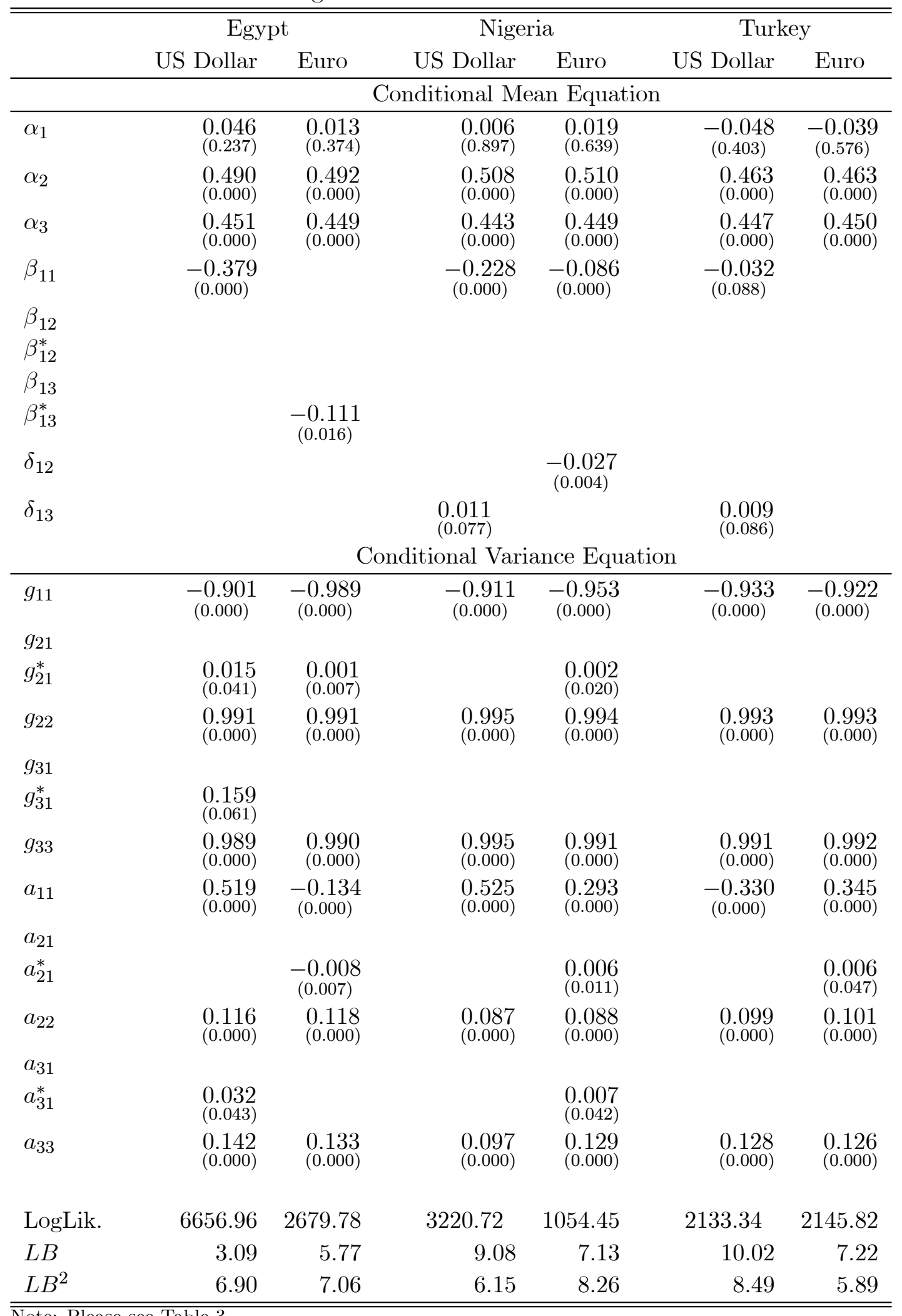

Note: Please see Table 3. 
Table 5: Conditional Correlations

\begin{tabular}{|c|c|c|c|c|c|c|c|c|}
\hline \multirow[b]{3}{*}{ Ex. Rate } & \multicolumn{4}{|c|}{ Pre 2008} & \multicolumn{4}{|c|}{ Post 2008} \\
\hline & \multicolumn{2}{|c|}{ Domestic News } & \multicolumn{2}{|c|}{ USA News } & \multicolumn{2}{|c|}{ Domestic News } & \multicolumn{2}{|c|}{ USA News } \\
\hline & Mean & S.D. & Mean & S.D. & Mean & S.D. & Mean & S.D. \\
\hline Czech Rep. & -0.011 & 0.069 & 0.032 & 0.132 & -0.008 & 0.107 & 0.013 & 0.123 \\
\hline Hungary & -0.033 & 0.058 & 0.015 & 0.051 & -0.040 & 0.067 & 0.029 & 0.085 \\
\hline Poland & -0.004 & 0.008 & 0.056 & 0.125 & -0.048 & 0.045 & 0.027 & 0.136 \\
\hline Argentina & -0.023 & 0.034 & 0.081 & 0.191 & -0.144 & 0.151 & 0.008 & 0.175 \\
\hline Mexico & -0.015 & 0.091 & 0.004 & 0.117 & -0.025 & 0.105 & 0.014 & 0.146 \\
\hline South Korea & -0.003 & 0.061 & 0.052 & 0.131 & -0.019 & 0.094 & 0.037 & 0.146 \\
\hline Egypt & -0.008 & 0.088 & 0.013 & 0.134 & -0.048 & 0.143 & 0.108 & 0.163 \\
\hline Nigeria & -0.014 & 0.045 & 0.016 & 0.079 & -0.027 & 0.097 & 0.052 & 0.112 \\
\hline \multirow[t]{2}{*}{ Turkey } & -0.007 & 0.074 & 0.011 & 0.107 & -0.006 & 0.076 & 0.005 & 0.129 \\
\hline & \multicolumn{2}{|c|}{ Domestic News } & \multicolumn{2}{|c|}{ Euro News } & \multicolumn{2}{|c|}{ Domestic News } & \multicolumn{2}{|c|}{ Euro News } \\
\hline Ex. Rate & Mean & S.D. & Mean & S.D. & Mean & S.D. & Mean & S.D. \\
\hline Czech Rep. & -0.002 & 0.075 & 0.002 & 0.121 & -0.045 & 0.123 & 0.011 & 0.124 \\
\hline Hungary & -0.029 & 0.042 & 0.011 & 0.107 & -0.031 & 0.071 & 0.004 & 0.102 \\
\hline Poland & -0.011 & 0.064 & 0.009 & 0.061 & -0.055 & 0.092 & 0.025 & 0.085 \\
\hline Argentina & -0.004 & 0.003 & 0.013 & 0.111 & -0.016 & 0.069 & 0.075 & 0.127 \\
\hline Mexico & -0.029 & 0.096 & 0.014 & 0.091 & -0.002 & 0.109 & 0.078 & 0.094 \\
\hline South Korea & -0.026 & 0.065 & 0.016 & 0.103 & -0.013 & 0.113 & 0.021 & 0.111 \\
\hline Egypt & -0.021 & 0.051 & 0.006 & 0.085 & -0.053 & 0.082 & 0.009 & 0.106 \\
\hline Nigeria & -0.035 & 0.066 & 0.028 & 0.104 & -0.021 & 0.102 & 0.023 & 0.109 \\
\hline Turkey & -0.004 & 0.067 & 0.009 & 0.108 & -0.015 & 0.068 & 0.073 & 0.097 \\
\hline
\end{tabular}

$\overline{\text { Conditional correlations between foreign exchange markets and domestic and foreign news respectively }}$ are given by : $\rho_{12, t}=h_{12, t} / \sqrt{h_{11, t}} \sqrt{h_{22, t}}$ and $\rho_{13, t}=h_{13, t} / \sqrt{h_{11, t}} \sqrt{h_{33, t}}$ 
Figure 1: Changes in exchange rates vis-a-vis the Euro
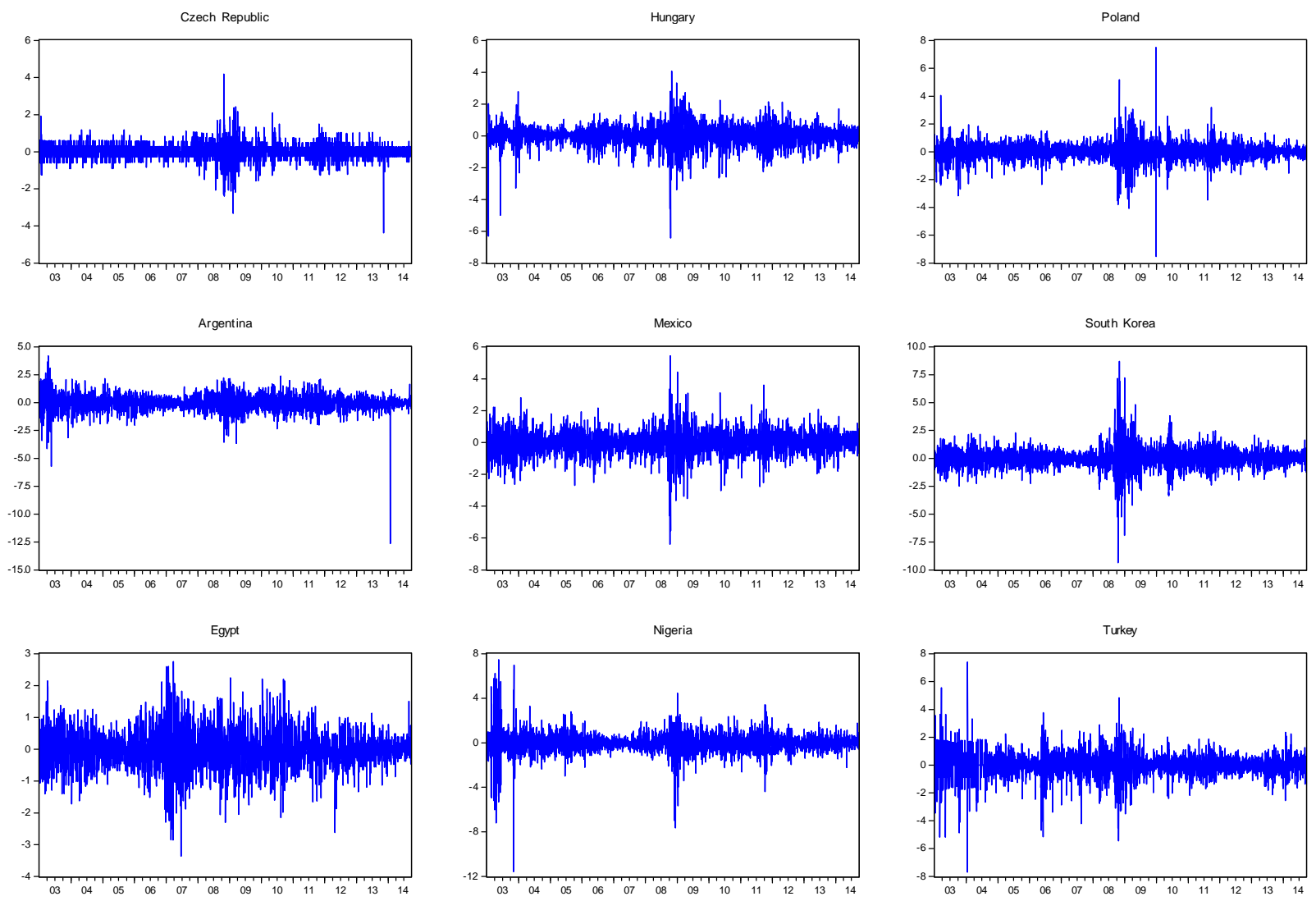
Figure 2: Changes in exchange rates vis-a-vis the US dollar
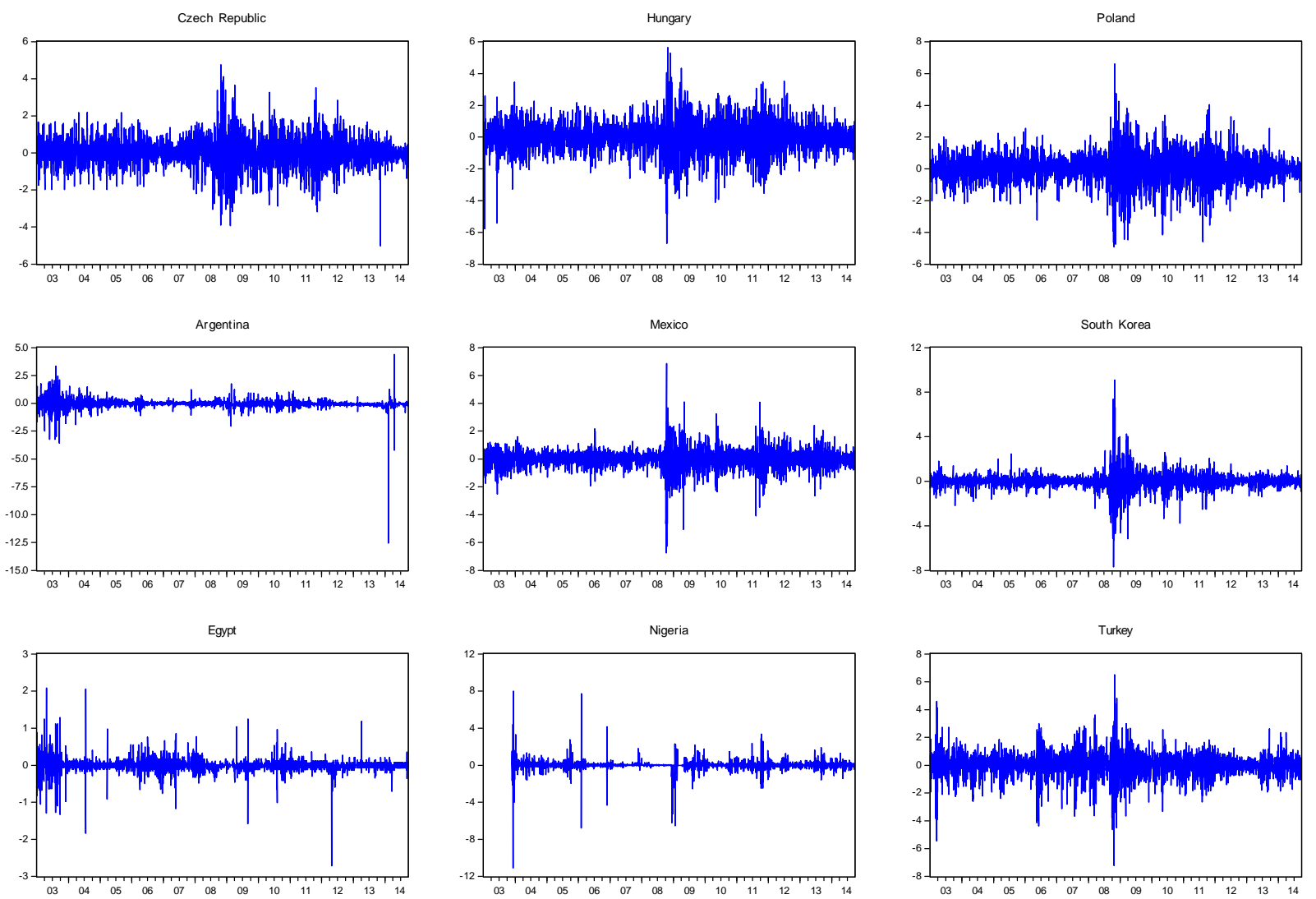
Figure 3: News coverage of four macroeconomic series, i.e. GDP, unemployment, retail sales and durable goods is considered. News coverage is proxied by story headlines counts. All news classified as potential negative were counted. Then all news, potentially negative and positive were counted. The ratio of latter to former is the negative macro news index. Therefore, the daily negative news percentage is defined as negative news/(negative news + positive news).
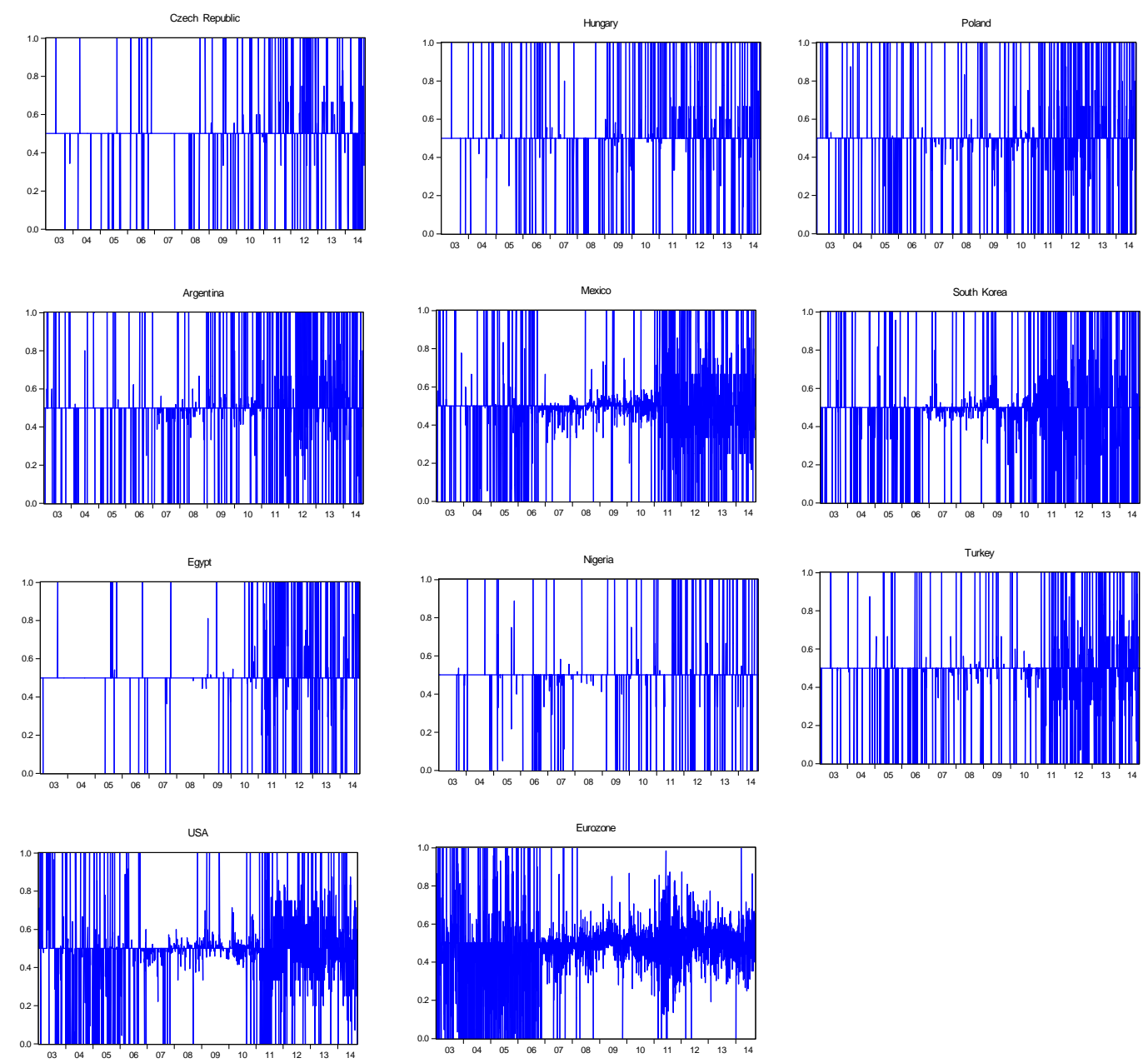